\title{
Analisis Perbandingan Algoritma Klasifikasi Citra Chest X-ray Untuk Deteksi Covid-19
}

\author{
Mohammad Farid Naufal ${ }^{1 *}$, Selvia Ferdiana Kusuma ${ }^{2}$, Kevin Christian Tanus ${ }^{3}$, Raynaldy Valentino \\ Sukiwun $^{4}$, Joseph Kristiano ${ }^{5}$, Jeremy Owen Lieyanto ${ }^{6}$, Daniel Cristianindra R. ${ }^{7}$ \\ 1,3,4,5,6 Jurusan Teknik Informatika, Universitas Surabaya, Surabaya, Jawa Timur \\ ${ }^{2}$ Manajemen Informatika, PSDKU Politeknik Negeri Malang, Kediri, Jawa Timur \\ Email: ${ }^{1 *}$ faridnaufal@staff.ubaya.ac.id, ${ }^{2}$ selvia.ferdiana@ polinema.ac.id, ${ }^{3}$ s160418043@ student.ubaya.ac.id, \\ 4s160417116@student.ubaya.ac.id, 5s160418015@student.ubaya.ac.id, ${ }^{4}$ s160418081@student.ubaya.ac.id, \\ ${ }^{7}$ s160417092@student.ubaya.ac.id
}

(Naskah masuk: 15 Jan 2021, direvisi: 12 Jun 2021, diterima: 15 Jun 2021)

\begin{abstract}
Abstrak
Kondisi pandemi global Covid-19 yang muncul diakhir tahun 2019 telah menjadi permasalahan utama seluruh negara di dunia. Covid-19 merupakan virus yang menyerang organ paru-paru dan dapat mengakibatkan kematian. Pasien Covid-19 banyak yang telah dirawat di rumah sakit sehingga terdapat data citra chest $X$-ray paru-paru pasien yang terjangkit Covid-19. Saat ini sudah banyak peneltian yang melakukan klasifikasi citra chest X-ray menggunakan Convolutional Neural Network (CNN) untuk membedakan paru-paru sehat, terinfeksi covid-19, dan penyakit paru-paru lainnya, namun belum ada penelitian yang mencoba membandingkan performa algoritma CNN dan machine learning klasik seperti Support Vector Machine (SVM), dan K-Nearest Neighbor $(K N N)$ untuk mengetahui gap performa dan waktu eksekusi yang dibutuhkan. Penelitian ini bertujuan untuk membandingkan performa dan waktu eksekusi algoritma klasifikasi K-Nearest Neighbors (KNN), Support Vector Machine (SVM), dan CNN untuk mendeteksi Covid-19 berdasarkan citra chest X-Ray. Berdasarkan hasil pengujian menggunakan 5 Cross Validation, CNN merupakan algoritma yang memiliki rata-rata performa terbaik yaitu akurasi 0,9591, precision 0,9592, recall 0,9591, dan F1 Score 0,959 dengan waktu eksekusi rata-rata sebesar 3102,562 detik.
\end{abstract}

Kata Kunci: CNN, SVM, KNN, Chest X-ray, Covid-19

\section{Comparative Analysis of Chest X-ray Image Classification Algorithms for Covid-19 Detection}

\begin{abstract}
Condition of the global Covid-19 pandemic that emerged at the end of 2019 has become a major problem for all countries in the world. Covid-19 is a virus that attacks the lungs and can cause death. Many Covid-19 patients have been hospitalized so there is chest $x$-ray image data of patients infected with Covid-19. Currently, there are many studies that classify chest $X$-ray images using the Convolutional Neural Network (CNN) to distinguish healthy lungs, Covid-19 infection, and other lung diseases, but no research has attempted to compare the CNN algorithm classical machine learning algorithm such as the K-Nearest Neighbor (KNN) and Support Vector Machine (SVM) to see the performance and execution time gap. This study aims to compare the performance and execution time of the K-Nearest Neighbors (KNN), Support Vector Machine (SVM), and CNN algorithms for detecting Covid-19 based on X-Ray chest images. Based on the test results using 5 Cross Validation, CNN is the algorithm that has the best performance, namely 0.9591 accuracy, 0.9592 precision, 0.9591 recall, and F1 Score 0.959 with an average execution time of 3102.562 seconds.
\end{abstract}

Keywords: CNN, SVM, KNN, Chest X-ray, Covid-19. 


\section{PENDAHULUAN}

Tahun 2019 merupakan awal mula dari munculnya kasus Corona Virus Disease - 19, yang disebut juga dengan Covid19, pertama kali muncul di Wuhan, China. Semenjak saat itu, lonjakan orang yang terinfeksi Covid-19 mulai melonjak yang tadinya hanya berjumlah puluhan orang yang kemudian persebaran virus ini terus naik hingga akhirnya Covid-19 ini terus tersebar hingga ke penjuru dunia. Dalam perkembangannya, tingkat penularan Covid-19 juga dinilai cukup tinggi. Sampai saat ini, di bulan Januari 2021, di saat penulisan artikel ini ditulis, total kasus Covid-19 di dunia sudah menginjak hingga kurang lebih 86.248.818 kasus positif, dengan total 61.197 .913 pasien sembuh, dan total kasus kematian hingga 1.863.861 kasus [1].

Shi, et.al. [2] melakukan analisis deskriptif terhadap 81 pasien Covid-19 menggunakan radiological CT dan menyatakan bahwa citra Chest CT dan X-Ray dapat secara efektif mendeteksi Covid-19 pada pasien dengan gejala. Islam et.al. [3] menyatakan bahwa diagnosis Covid-19 menggunakan citra Chest $X$-ray dapat digunakan sebagai tes tambahan jika pasien dinyatakan negatif pada tes PCR namun memiliki gejala. Yasin, et.al. [4] melakukan monitoring citra Chest X-ray pada pasien Covid-19 dan memberikan kesimpulan bahwa citra Chest $X$-ray dapat digunakan untuk monitoring jangka panjang pasien. Dari beberapa penelitian tersebut dapat dikatakan bahwa citra Chest $X$-ray adalah dataset yang berguna bagi tenaga medis untuk menangani pasien Covid-19.

Gao, et.al. [5] menggunakan CNN dengan arsitektur VGG-19 dalam melakukan klasifikasi citra Chest X-Ray ke dalam 3 kategori yaitu normal, covid, dan bacterial pneumonia. Akurasi yang dihasilkan 95\%. Abbas, et.al. [6] menggunakan Decompose, Transfer, Compose (DeTraC) CNN untuk klasifikasi Chest X-Ray menjadi 3 kategori, yaitu normal, Covid-19, dan SARS. Akurasi yang dihasilkan mencapai 93,1\%. Deng, et.al. [7] menggunakan pre-trained model Keras pada data Chest X-ray dan Chest CT. Akurasi yang dihasilkan dikedua dataset tersebut adalah $84 \%$ dan $75 \%$. Performa yang dihasilkan tersebut masih memiliki akurasi di bawah 90\%. Dari beberapa penelitian yang disebutkan belum ada penelitian yang mencoba untuk membandingkan performa algoritma machine learning klasik seperti K-Nearest Neighbors, Support Vector Machine (SVM), dengan algoritma Neural network yaitu Convolutional Neural Network (CNN) dalam melakukan deteksi Covid-19 pada citra Chest X-ray.

Berdasarkan penelitian yang sudah dilakukan sebelumnya, belum terdapat penelitian yang bertujuan untuk membandingkan performa algoritma klasifikasi pada dataset Chest $X$-ray yang sama. Selain itu belum ada penelitian yang membahas tentang hubungan antara waktu komputasi dan performa algoritma klasifikasi. Penelitian ini bertujuan untuk membandingkan performa beberapa algoritma dalam melakukan klasifikasi terhadap citra Chest X-ray ke dalam kategori paru-paru yang sehat, paru-paru yang terjangkit Covid-19, serta paru-paru yang terjangkit penyakit lainnya, dalam kasus ini adalah viral pneumonia. Algoritma yang dibandingkan dalam penelitian ini adalah KNN, SVM, dan CNN. Fitur yang digunakan dalam melakukan klasifikasi adalah intensitas pixel. Performa yang dibandingkan antara lain akurasi, precision, recall, fl score, dan waktu eksekusi. Perbandingan performa algoritma ke depannya diharapkan dapat berguna untuk peneliti dalam memilih algoritma untuk melakukan klasifikasi citra Chest X-ray. Tujuan aplikatif penelitian ini adalah mengetahui perbandingan algoritma klasifikasi yang akan memudahkan peneliti dan praktisi dalam memilih algoritma yang paling tepat untuk klasifikasi Citra Chest X-Ray untuk deteksi Covid-19.

Sistematika penelitian ini terdiri dari 4 bagian. Pada bab 1 dijelaskan mengenai latar belakang masalah penelitian. Pada bab 2 dijelaskan mengenai metodologi penelitian. Pada bab 3 dijelaskan mengenai hasil dan pembahasan. Pada bab 4 dijelaskan mengenai kesimpulan.

\section{METODOLOGI PENELITIAN}

Metodologi penelitian yang digunakan terdiri dari 5 tahapan, yaitu pengumpulan dataset, pembentukan model klasifikasi, training model klasifikasi, testing model klasifikasi, dan perhitungan performa. Gambar 1 menunjukkan alur metodologi penelitian yang digunakan.

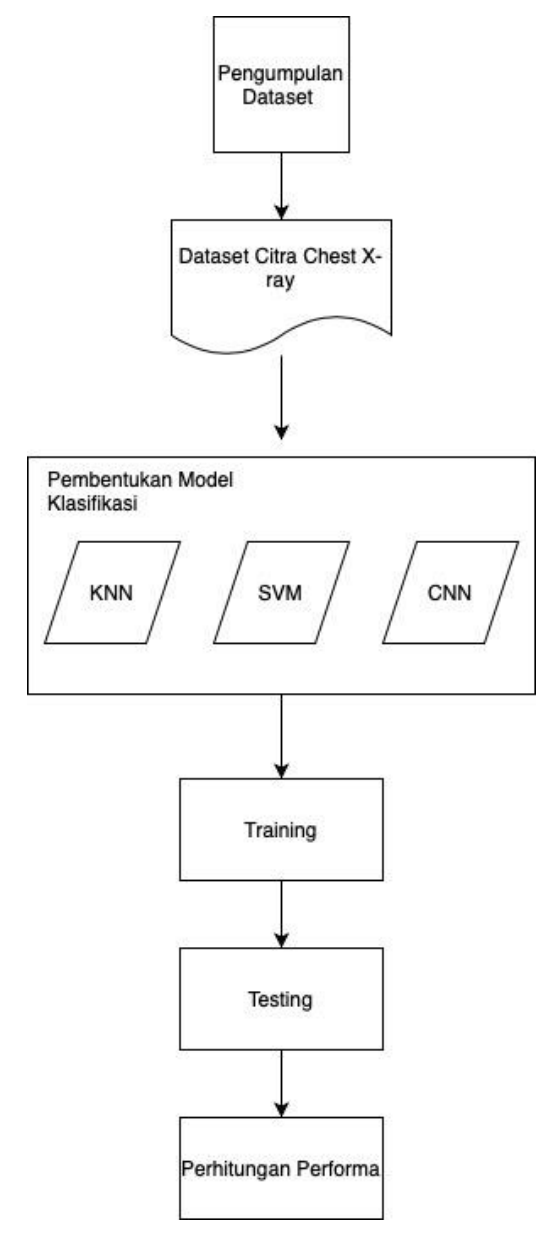

Gambar 1. Metodologi Penelitian 


\section{A. Pengumpulan Dataset}

Dataset yang digunakan dalam penelitian ini adalah citra Chest X-ray yang didapatkan dari Kaggle [8]. Tujuan penggunaan dataset dari Kaggle adalah dataset ini dapat diakses publik sehingga dapat dibandingkan dengan penelitian selanjutnya. Dataset terdiri dari 3 jenis atau label citra Chest $X$-ray, yaitu paru-paru normal, terinfeksi Covid-19, dan viral pneumonia. Gambar 2 menunjukkan contoh citra Chest $X$-ray paru-paru normal, terinfeksi Covid-19, dan viral pneumonia. Tabel 1 menununjukkan detail jumlah dataset dari tiap jenis Citra Chest X-ray. Dikarenakan dataset citra Chest X-ray memiliki ukuran citra yang berbeda-beda, maka semua data citra Chest X-ray dilakukan resize dengan ukuran 64x64.

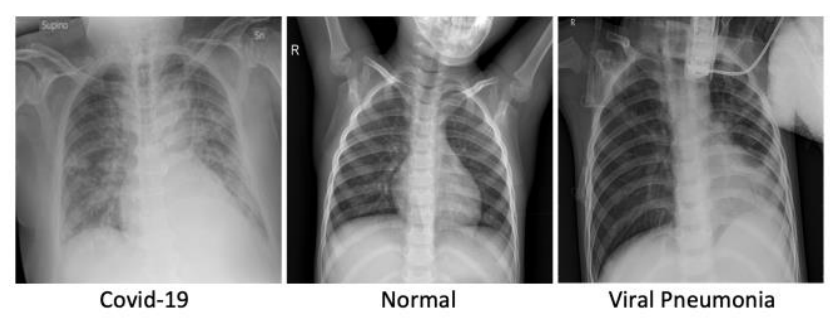

Gambar 2. Contoh Citra Chest X-ray

Tabel 1. Detail Jumlah Dataset Citra Chest X-ray

\begin{tabular}{lr}
\hline \multicolumn{1}{c}{ Jenis } & \multicolumn{1}{c}{ Jumlah } \\
\hline Normal & 1341 \\
\hline Covid-19 & 1200 \\
\hline Viral Pneumonia & 1345 \\
\hline
\end{tabular}

B. Pembentukan Model Klasifikasi

Pada tahapan ini dilakukan konfigurasi berbagai parameter yang digunakan dari algoritma KNN, SVM, dan CNN. Tujuannya adalah agar mengetahui pengaruh dari parameter terhadap performa algoritma.

\section{1) $\mathrm{KNN}$}

Konfigurasi parameter yang digunakan pada algoritma KNN adalah jumlah Neighbors dan jenis distance. Tabel 2 menunjukkan konfigurasi parameter yang digunakan dalam algoritma KNN. Jumlah Neighbors yang digunakan adalah 5, 7, dan 9. Sedangkan jenis distance yang digunakan adalah Euclidean, Manhattan, dan Minkowski. Setiap distance dilakukan uji coba dengan jumlah neighbors sebanyak 5, 7, dan 9 .

Tabel 2. Parameter KNN

\begin{tabular}{ll}
\hline \multicolumn{1}{c}{ Parameter } & \multicolumn{1}{c}{ Deskripsi } \\
\hline Jumlah Neighbors & $5,7,9$ \\
\hline Distance & Euclidean, Minkowski \\
\hline
\end{tabular}

\section{2) SVM}

Konfigurasi parameter yang digunakan pada algoritma SVM adalah jenis kernel. Tabel 3 menunjukkan konfigurasi parameter yang digunakan dalam algoritma SVM. Jenis kernel yang digunakan adalah Linear, Poly, dan RBF. Pada tahapan training akan dipilih salah satu kernel yang memiliki performa terbaik.

Tabel 3. Parameter KNN

\begin{tabular}{cc}
\hline Parameter & Deskripsi \\
\hline Kernel & Linear, Poly, RBF \\
\hline
\end{tabular}

3) $\mathrm{CNN}$

Konfigurasi parameter yang digunakan pada algoritma CNN adalah jumlah epoch, model convolution, jenis activation function, jumlah dense layer, dan jumlah batch size. Tabel 4 menunjukkan parameter CNN yang digunakan.

Tabel 4. Parameter CNN

\begin{tabular}{lll}
\hline \multicolumn{1}{c}{ Parameter } & \multicolumn{1}{c}{ Output Shape } & \multicolumn{1}{c}{ Deskripsi } \\
\hline conv2d & $($ None $, 62,62,32)$ & $\begin{array}{l}\text { Filter_size }= \\
3 \times 3 . \text { Act }=R e L u\end{array}$ \\
\hline (MaxPooling2D $)$ & $($ None $, 31,31,32)$ & Pool_size $=2$ \\
\hline Conv2D $)$ & $($ None $, 29,29,32)$ & $\begin{array}{l}\text { Filter_size }= \\
\text { 3x3. Act }=\text { ReLu }\end{array}$ \\
\hline (MaxPooling2D $)$ & $($ None $, 14,14,32)$ & Pool_size $=2$ \\
\hline (Flatten $)$ & $($ None, 6272$)$ & - \\
\hline (Dense $)$ & $($ None, 128$)$ & Act $=$ ReLu \\
\hline (Dense $)$ & $($ None, 3$)$ & Act $=$ Softmax \\
\hline epoch & - & 50 \\
\hline optmizer & - & Adam \\
\hline Batch_size & - & 8 \\
\hline
\end{tabular}

Activation function pada dua tahapan convolution dan dense pada layer pertama adalah Rectified Linear Unit $($ ReLu). Rumus activation function ReLu dapat dilihat pada persamaan (1). $x$ adalah nilai yang dimasukkan ke activation function.

$R(x)=\max (0, x)$

Sedangkan activation function pada dense layer kedua adalah softmax dikarenakan terdapat 3 label klasifikasi. Rumus activation function softmax dapat dilihat pada persamaan (2). $x_{i}$ adalah nilai input yang berasal dari layer sebelumnya, $n$ adalah jumlah label, dan $j$ adalah urutan label.

$S\left(x_{i}\right)=\frac{e^{x_{i}}}{\sum_{j}^{n} e^{x_{j}}}$

Epoch yang digunakan saat proses training adalah 50. Optimizer untuk memperbarui bobot edge pada tiap layer adalah Adam optimizer. Batch size yang digunakan adalah 8.

\section{4) Spesifikasi Perangkat Keras}

Semua model klasifikasi yang dibentuk, proses training dan testing dieksekusi pada sebuah komputer dengan spesifikasi pada Tabel 5. Parameter Spesifikasi yang ditampilkan adalah CPU, RAM, Space of Disk, dan GPU Model Name. Informasi spesifikasi ini penting dikarenakan berpengaruh pada performa waktu eksekusi yang diteliti. 
Tabel 5. Spesifikasi Perangkat Keras

\begin{tabular}{ll}
\hline \multicolumn{1}{c}{ Parameter } & \multicolumn{1}{c}{ Spesifikasi } \\
\hline CPU & $\begin{array}{l}\text { Intel® Core } \\
\text { @M } 3.30 \mathrm{GHz} \text { (4 CPUs) }\end{array}$ \\
\hline RAM & 8192 MB \\
\hline Operating System & $\begin{array}{l}\text { Windows 10 Education 64- } \\
\text { bit (10.0, Build 17763) }\end{array}$ \\
\hline GPU Model Name & $\begin{array}{l}\text { AMD Radeon HD 5500 } \\
\text { Series }\end{array}$ \\
\hline GPU Total Memory & $1 \mathrm{~GB}$ \\
\hline
\end{tabular}

\section{Training}

Pada tahapan training dan testing, dataset yang digunakan dibagi menjadi dua bagian dengan proporsi $80 \%$ training dan $20 \%$ testing, sehingga jumlah cross validation yang digunakan adalah 5. Pembagian data training dan testing tersebut dilakukan secara acak.

Training dilakukan untuk algoritma KNN, SVM, dan CNN dengan menggunakan parameter yang telah dijelaskan pada subbab sebelumnya. Pada algoritma CNN, terdapat tahapan data augmentation untuk memperkaya variasi dari dataset. Semakin bervariasi dataset training berguna untuk menghindari terjadinya overfitting. Jenis data augmentation yang digunakan adalah horizontal flip, shear range, dan zoom range. Data augmentation dilakukan menggunakan library Keras [9].

Horizontal flip digunakan menduplikasi dataset training dengan cara merotasi citra sebesar 90 derajat. Shear range [10] melakukan shear transformation yang berguna untuk merotasi citra dengan derajat tertentu sesuai dengan parameter. Zoom range digunakan untuk memperbesar citra dengan ukuran tertentu sesuai dengan parameter.

\section{Testing}

Tahapan testing dilakukan untuk memvalidasi model yang telah terbentuk pada tahapan training. Testing dilakukan di setiap cross validation untuk algoritma KNN, SVM, dan CNN. Testing menggunakan cross validation bertujuan untuk melihat apakah model yang dibangun di algoritma memiliki performa yang stabil atau tidak.

Pada algoritma CNN, validasi dilakukan di setiap epoch menggunakan data testing. Jika terdapat model di epoch tertentu yang memiliki performa terbaik, maka model tersebut akan disimpan. Penyimpanan model terbaik menggunakan checkpoint yang merupakan library di Keras.

\section{E. Perhitungan Performa}

Pada tahapan ini dilakukan proses perhitungan performa dari tahapan testing di setiap algoritma. Metric performa yang digunakan adalah accuracy, precision, recall, fl score, dan waktu eksekusi proses training dan testing. Setiap algoritma dengan parameternya masing-masing dihitung performanya di setiap cross validation dan kemudian dihitung rata-ratanya. Parameter disebuah algoritma yang memiliki performa terbaik akan dipilih dan kemudian dibandingkan dengan algoritma yang lain yang memiliki parameter dengan performa yang terbaik.
Persamaan (3) menunjukkan perhitungan accuracy. Accuracy digunakan untuk menghitung total dari True Positive (TP) dan True Negative (TN) dibagi dengan total dari TP, TN, False Positive (FP), dan False Negative (FN).

Accuracy $=\frac{T P+T N}{T P+T N+F P+F N}$

Persamaan (4) menunjukkan rumus perhitungan dari Precision. Precision dihitung dengan cara membagi TP dengan total dari TP dan FP.

Precision $=\frac{T P}{T P+F P}$

Persamaan (5) menunjukkan rumus perhitungan dari recall. Recall dihitung dengan cara membagi anatara TP dengan total dari TP dan FN.

Recall $=\frac{T P}{T P+F N}$

Persamaan (6) menunjukkan rumus perhitungan dari $f l$ Score. F1 Score dihitung dengan cara membagi antara perkalian Precision dengan Recall dan penambahan Precision dan Recall.

$F 1$ Score $=\frac{\text { Precision } x \text { Recall }}{\text { Precision }+ \text { Recall }}$

Perhitungan rumus precision, recall, dan fl score pada kasus ini menggunakan weighted metric. Weighted metric digunakan untuk kasus klasifikasi multiclass. Dataset citra Chest $X$-ray yang digunakan pada kasus ini memiliki jumlah yang berbeda tiap kelas klasifikasinya seperti yang ada pada Tabel 1. Rumus perhitungan weighted metric dapat dilihat pada Persamaan (7). $p_{i}$ adalah metric performa precision, recall, dan $f 1$ score untuk masing-masing kelas $i . c_{i}$ adalah jumlah dataset pada masing-masing kelas $i$.

$W_{m}=\frac{\sum_{i}^{j} p_{i} c_{i}}{\sum_{i}^{j} c_{i}}$

\section{HASIL DAN PEMBAHASAN}

Pada tahapan ini akan dijelaskan mengenai hasil uji coba klasifikasi citra Chest $X$-ray menggunakan algoritma KNN, SVM, dan CNN. Kemudian akan dijelaskan pula mengenai hasil perbandingan dari tiap algoritma tersebut.

\section{A. Hasil Uji Coba Algoritma KNN}

Tabel 6 menunjukkan hasil uji coba algoritma KNN dengan parameter distance dan jumlah neighbors yang telah ditentukan. Dist adalah jenis distance, NN adalah Number of Neighbors atau jumlah neighbor, AVG adalah rata-rata nilai metric, dan AVG Perf adalah jumlah dari rata-rata metric accuracy, precision, recall, dan fl score dibagi dengan 4 . AVG Perf digunakan untuk melihat rata-rata performa metric secara keseluruhan. 
Dapat terlihat bahwa tidak ada perbedaan performa yang signifikan dengan parameter yang digunakan pada KNN. Namun dalam penelitian ini KNN dengan tipe distance Minkowski dan NN sejumlah 7 yang memiliki AVG Perf sebesar 0,921 dipilih untuk dibandingkan dengan algoritma SVM dan CNN dikarenakan memiliki AVG Perf terbaik.

Tabel 6. Hasil Uji Coba Algoritma KNN

\begin{tabular}{|c|c|c|c|c|c|c|c|c|c|}
\hline \multirow[t]{2}{*}{ Dist } & \multirow[t]{2}{*}{$\mathbf{N N}$} & \multirow[t]{2}{*}{ Metric } & \multicolumn{5}{|c|}{ Cross Validation } & \multirow[t]{2}{*}{ AVG } & \multirow{2}{*}{$\begin{array}{l}\text { AVG } \\
\text { PERF }\end{array}$} \\
\hline & & & 1 & 2 & 3 & 4 & 5 & & \\
\hline \multirow{12}{*}{ 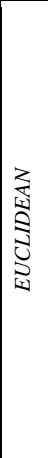 } & \multirow[t]{4}{*}{5} & ACC & 0,9177 & 0,9189 & 0,9099 & 0,9305 & 0,9228 & 0,92 & \multirow{4}{*}{0,9204} \\
\hline & & PREC & 0,9198 & 0,9198 & 0,9124 & 0,9307 & 0,9239 & 0,9213 & \\
\hline & & REC & 0,9177 & 0,9189 & 0,9099 & 0,9305 & 0,9228 & 0,92 & \\
\hline & & F1SCORE & 0,9182 & 0,9192 & 0,9102 & 0,9306 & 0,923 & 0,9202 & \\
\hline & \multirow[t]{4}{*}{7} & ACC & 0,9152 & 0,9292 & 0,9086 & 0,9266 & 0,9202 & 0,92 & \multirow{4}{*}{0,9207} \\
\hline & & PREC & 0,9197 & 0,9311 & 0,9128 & 0,9269 & 0,9215 & 0,9224 & \\
\hline & & REC & 0,9152 & 0,9292 & 0,9086 & 0,9266 & 0,9202 & 0,92 & \\
\hline & & F1SCORE & 0,9159 & 0,9296 & 0,9092 & 0,9266 & 0,9205 & 0,9204 & \\
\hline & \multirow[t]{4}{*}{9} & ACC & 0,9152 & 0,9292 & 0,9086 & 0,9266 & 0,9202 & 0,92 & \multirow{4}{*}{0,9204} \\
\hline & & PREC & 0,9198 & 0,9198 & 0,9124 & 0,9307 & 0,9239 & 0,9213 & \\
\hline & & REC & 0,9152 & 0,9292 & 0,9086 & 0,9266 & 0,9202 & 0,92 & \\
\hline & & F1SCORE & 0,9159 & 0,9296 & 0,9092 & 0,9266 & 0,9205 & 0,9204 & \\
\hline \multirow{12}{*}{$\begin{array}{l}\gtrsim \\
\vdots \\
\vdots \\
\vdots \\
\vdots \\
\vdots \\
\vdots\end{array}$} & \multirow[t]{4}{*}{5} & ACC & 0,9177 & 0,9189 & 0,9099 & 0,9305 & 0,9228 & 0,92 & \multirow{4}{*}{0,9192} \\
\hline & & PREC & 0,9198 & 0,9198 & 0,9124 & 0,9307 & 0,9239 & 0,9213 & \\
\hline & & REC & 0,9177 & 0,9189 & 0,9099 & 0,9189 & 0,9228 & 0,9177 & \\
\hline & & F1SCORE & 0,9182 & 0,9192 & 0,9102 & 0,9192 & 0,923 & 0,918 & \\
\hline & \multirow[t]{4}{*}{7} & ACC & 0,9152 & 0,9292 & 0,9086 & 0,9266 & 0,9202 & 0,92 & \multirow{4}{*}{0,921} \\
\hline & & PREC & 0,9197 & 0,9311 & 0,9128 & 0,9269 & 0,9215 & 0,9224 & \\
\hline & & REC & 0,9152 & 0,9292 & 0,9086 & 0,9292 & 0,9202 & 0,9205 & \\
\hline & & F1SCORE & 0,9159 & 0,9296 & 0,9092 & 0,9296 & 0,9205 & 0,921 & \\
\hline & \multirow[t]{4}{*}{9} & ACC & 0,9152 & 0,9292 & 0,9086 & 0,9266 & 0,9202 & 0,92 & \multirow{4}{*}{0,9207} \\
\hline & & PREC & 0,9198 & 0,9198 & 0,9124 & 0,9307 & 0,9239 & 0,9213 & \\
\hline & & REC & 0,9152 & 0,9292 & 0,9086 & 0,9292 & 0,9202 & 0,9205 & \\
\hline & & F1SCORE & 0,9159 & 0,9296 & 0,9092 & 0,9296 & 0,9205 & 0,921 & \\
\hline
\end{tabular}

B. Hasil Uji Coba Algoritma SVM

Tabel 7 menunjukkan hasil uji coba pada algoritma SVM. Terdapat perbedaan performa yang cukup signifikan diantara kernel. Dapat dilihat bahwa algoritma SVM dengan tipe kernel Linear memiliki AVG Perf terbaik yaitu sebesar 0,930. Selanjutnya performa SVM dengan kernel Linear akan dibandingkan dengan algoritma KNN dan $\mathrm{CNN}$.

Tabel 7. Hasil Uji Coba Algoritma SVM

\begin{tabular}{|c|c|c|c|c|c|c|c|c|}
\hline \multirow{2}{*}{ Kernel } & \multirow{2}{*}{ Metric } & \multicolumn{5}{|c|}{ Cross Validation } & \multirow{2}{*}{ AVG } & \multirow{2}{*}{ AVG PERF } \\
\hline & & 1 & 2 & 3 & 4 & 5 & & \\
\hline \multirow{4}{*}{ 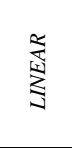 } & ACC & 0,929 & 0,923 & 0,933 & 0,937 & 0,927 & 0,93 & \multirow{4}{*}{0.930} \\
\hline & PREC & 0,93 & 0,923 & 0,934 & 0,937 & 0,937 & 0,932 & \\
\hline & REC & 0,929 & 0,923 & 0,933 & 0,937 & 0,927 & 0,93 & \\
\hline & F1SCORE & 0,929 & 0,923 & 0,933 & 0,937 & 0,927 & 0,93 & \\
\hline \multirow{4}{*}{$\begin{array}{l}\overrightarrow{0} \\
2\end{array}$} & ACC & 0,812 & 0,815 & 0,793 & 0,807 & 0,835 & 0,812 & \multirow{4}{*}{0.815} \\
\hline & PREC & 0,825 & 0,821 & 0,808 & 0,836 & 0,836 & 0,825 & \\
\hline & REC & 0,812 & 0,815 & 0,793 & 0,807 & 0,835 & 0,812 & \\
\hline & F1SCORE & 0,813 & 0,815 & 0,79 & 0,802 & 0,834 & 0,811 & \\
\hline \multirow{4}{*}{$\stackrel{\vec{q}}{\approx}$} & ACC & |0,904 & 0,9 & 0,916 & 0,915 & 0,902 & 0,907 & \multirow{4}{*}{0.908} \\
\hline & PREC & 0,906 & 0,9 & 0,917 & 0,915 & 0,915 & 0,91 & \\
\hline & REC & |0,904 & 0,9 & 0,916 & 0,915 & 0,902 & 0,907 & \\
\hline & F1SCORE & 0,904 & 0,9 & 0,916 & $\mid 0,914$ & 0,902 & 0,907 & \\
\hline
\end{tabular}

\section{Hasil Uji Coba Algoritma CNN}

Tabel 8 menunjukkan hasil uji coba pada algoritma CNN. Performa yang dihasilkan oleh CNN cukup baik yaitu memiliki AVG Perf 0,9591. Dari setiap cross validation, performa yang dihasilkan CNN juga cukup stabil, semua metric performa menghasilkan nilai di atas 0,95 .

Tabel 8. Hasil Uji Coba Algoritma CNN

\begin{tabular}{|l|c|c|c|c|c|c|c|}
\hline \multirow{2}{*}{ Metric } & \multicolumn{5}{|c|}{ Cross Validation } & \multirow{2}{*}{ AVG } & \multirow{2}{*}{ AVG } \\
\cline { 2 - 7 } & $\mathbf{1}$ & $\mathbf{2}$ & $\mathbf{3}$ & $\mathbf{4}$ & $\mathbf{5}$ & & \multirow{2}{*}{0,959} \\
\hline ACC & 0,9537 & 0,9601 & 0,9537 & 0,9704 & 0,9575 & 0,9591 & \\
\hline PREC & 0,9535 & 0,9601 & 0,9538 & 0,9711 & 0,9575 & 0,9592 & \multirow{2}{*}{0,9591} \\
\hline REC & 0,9537 & 0,9601 & 0,9537 & 0,9704 & 0,9575 & 0,9591 & \\
\hline F1SCORE & 0,9536 & 0,9601 & 0,9537 & 0,9703 & 0,9575 & 0,959 & \\
\hline
\end{tabular}

\section{Perbandingan Performa}

Tabel 9 menunjukkan hasil perbandingan metric performa dari algoritma KNN, SVM, dan CNN. Untuk algoritma KNN dan SVM menggunakan parameter yang memiliki performa terbaik seperti yang sudah dijelaskan pada subbab sebelumnya. Terlihat bahwa CNN memiliki performa yang terbaik jika dibandingkan dengan algoritma KNN dengan jumlah NN 7 dan SVM dengan kernel Linear. CNN memiliki accuracy, precision, recall, dan $f 1$ score yang paling baik. Gambar 3 menunjukkan grafik perbandingan performa algoritma KNN, SVM, dan CNN.

Gap yang dimiliki antara algoritma KNN dengan SVM adalah sekitar 0,011. Sedangkan gap yang dimiliki antara CNN dengan KNN dan CNN dengan SVM masing-masing 0,0381 dan 0,291. Perbedaan performa antara KNN dan SVM tidak cukup jauh, namun KNN dan SVM memiliki gap yang cukup signifikan dengan $\mathrm{CNN}$.

Tabel 9. Perbandingan Performa Algoritma

\begin{tabular}{|c|c|c|c|c|c|c|c|c|}
\hline & \multirow{3}{*}{ Metric } & \multirow{2}{*}{\multicolumn{5}{|c|}{ Cross Validation }} & & \\
\hline \multirow{2}{*}{ Algoritma } & & & & & & & \multirow{2}{*}{ AVG } & \multirow{2}{*}{$\begin{array}{l}\text { AVG } \\
\text { PERF }\end{array}$} \\
\hline & & 1 & 2 & 3 & 4 & 5 & & \\
\hline \multirow{4}{*}{$\begin{array}{l}\text { KNN } 7 \\
\text { MINKOWSKI }\end{array}$} & ACC & 0,9152 & \begin{tabular}{|l|l|}
0,9292 \\
\end{tabular} & 0,9086 & 0,9266 & \begin{tabular}{l|l|}
0,9202 & \\
\end{tabular} & 0,92 & \multirow{4}{*}{0,9210} \\
\hline & PREC & \begin{tabular}{|l|l|} 
& \\
\end{tabular} & 0,9311 & 0,9128 & 0,9269 & 0,9215 & \begin{tabular}{|l|l|} 
& \\
\end{tabular} & \\
\hline & REC & \begin{tabular}{|l|l|}
0,9152 \\
\end{tabular} & 0,9292 & 0,9086 & 0,9292 & \begin{tabular}{|l|l}
0,9202 \\
\end{tabular} & 0,9205 & \\
\hline & F1SCORE & \begin{tabular}{|l|}
0,9159 \\
\end{tabular} & 0,9296 & 0,9092 & 0,9296 & 0,9205 & 0,921 & \\
\hline \multirow{4}{*}{$\begin{array}{l}\text { SVM } \\
\text { LINEAR }\end{array}$} & $\mathrm{ACC}$ & 0,929 & 0,923 & 0,933 & 0,937 & 0,927 & 0,93 & \multirow{4}{*}{0,930} \\
\hline & PREC & 0,93 & 0,923 & 0,934 & 0,937 & 0,937 & 0,932 & \\
\hline & REC & 0,929 & 0,923 & 0,933 & 0,937 & 0,927 & 0,93 & \\
\hline & F1SCORE & 0,929 & 0,923 & 0,933 & 0,937 & 0,927 & 0,93 & \\
\hline \multirow{4}{*}{$\mathrm{CNN}$} & ACC & 0,9537 & 0,9601 & 0,9537 & 0,9704 & 0,9575 & 0,9591 & \multirow{4}{*}{0,9591} \\
\hline & PREC & 0,9535 & 0,9601 & 0,9538 & 0,9711 & 0,9575 & 0,9592 & \\
\hline & REC & 0,9537 & 0,9601 & 0,9537 & 0,9704 & 0,9575 & 0,9591 & \\
\hline & F1SCORE & \begin{tabular}{|l|}
0,9536 \\
\end{tabular} & 0,9601 & \begin{tabular}{|l|l|}
0,9537 \\
\end{tabular} & 0,9703 & 0,9575 & 0,959 & \\
\hline
\end{tabular}

Tabel 10 menunjukkan perbandingan waktu eksekusi training dan testing. Waktu eksekusi yang dihitung adalah waktu eksekusi proses training yang ditambahkan dengan proses testing pada setiap cross validation. Dapat dilihat bahwa CNN memiliki waktu ekskusi yang paling lama yaitu 3102,562 detik walaupun memiliki performa yang terbaik. Sedangkan SVM dengan Kernel Linear memiliki rata-rata waktu eksekusi yang paling cepat yaitu sebesar 32,802 detik. 

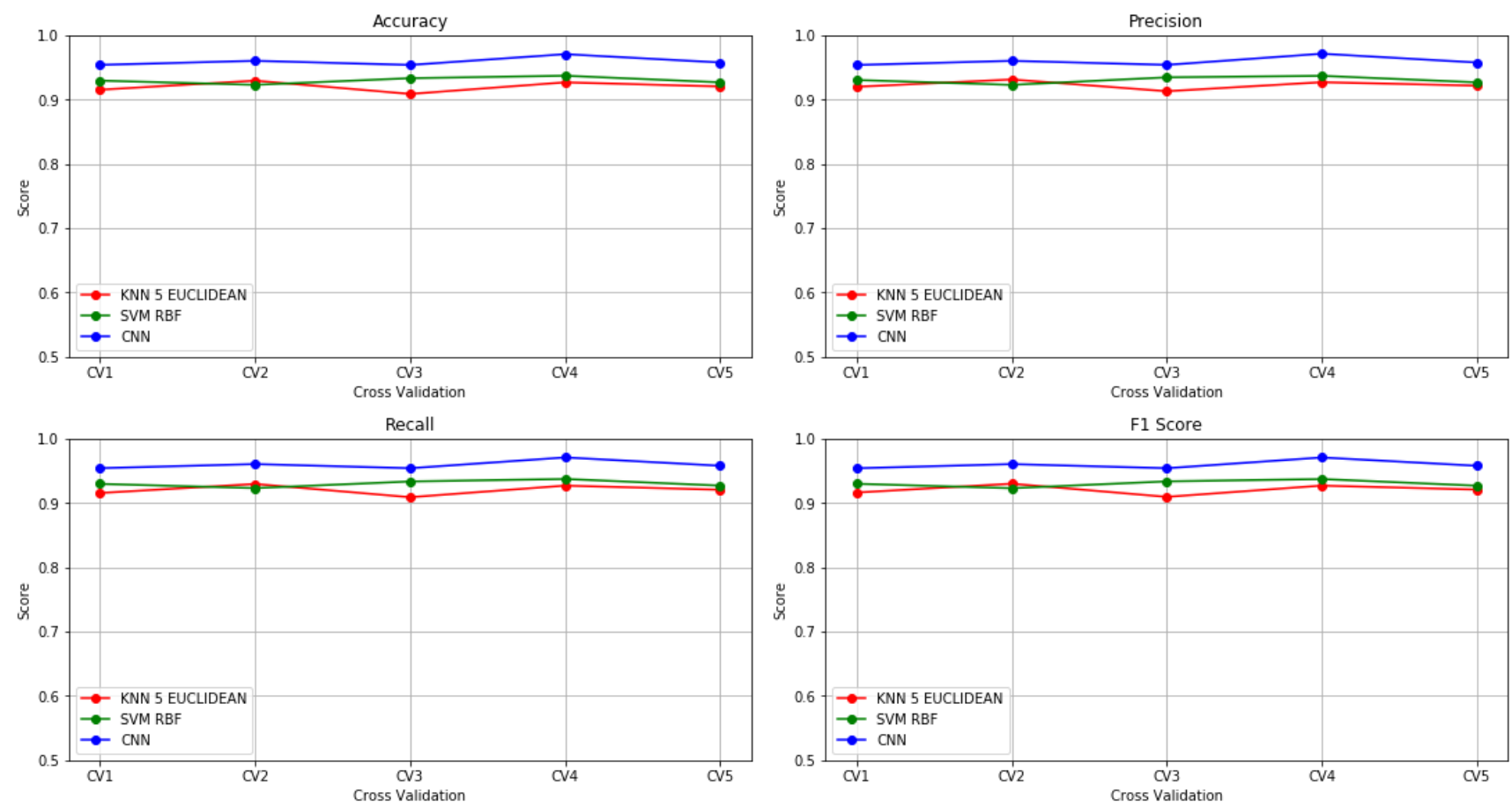

Gambar 3. Grafik Perbandingan Performa KNN, SVM, dan CNN

KNN memiliki rata-rata waktu eksekusi yang tidak jauh dengan SVM Linear yaitu sekitar 49,49.

Tabel 10. Perbandingan Waktu Eksekusi dalam Detik

\begin{tabular}{|c|c|c|c|c|c|c|}
\hline \multirow{2}{*}{ Algoritma } & \multicolumn{5}{|c|}{ Cross Validation } & \multirow{2}{*}{ AVG } \\
\hline & 1 & 2 & 3 & 4 & 5 & \\
\hline $\begin{array}{l}\text { KNN } 7 \\
\text { Minkowski }\end{array}$ & 52,56 & 48,50 & 48,61 & 48,81 & 48,97 & 49,49 \\
\hline SVM Linear & 34,91 & 32,44 & 32,70 & 32,09 & 31,87 & 32,802 \\
\hline $\mathrm{CNN}$ & 3154,36 & 3089,59 & 3091,79 & 3114,00 & 3063,07 & 3102,562 \\
\hline
\end{tabular}

Waktu eksekusi yang lama pada CNN dikarenakan epoch yang digunakan cukup banyak yaitu 50. Namun berdasarkan data history waktu eksekusi training dan testing dari setiap epochnya, CNN membutuhkan waktu rata-rata sebesar 61,5 detik dan memperoleh accuracy rata-rata 0,9 . Hal ini sesuai dengan sifat dari Neural Network yang membutuhkan lebih banyak waktu namun memiliki performance metric yang lebih baik.

Dari model training dan testing yang digunakan pada CNN, dapat disimpulkan bahwa model yang digunakan tidak mengalami overfitting, karena accuracy yang dihasilkan pada validasi data training tidak jauh berbeda dengan accuracy yang dihasilkan saat memvalidasi data testing. Gambar 4 menunjukkan Grafik Loss dan Accuracy dari setiap epoch pada CNN.

Algoritma KNN dengan distance Minkowski NN 7, SVM dengan Kernel Linear, dan CNN tergolong cukup stabil performanya di tiap cross validation. Hal ini dapat dikatakan bahwa algoritma SVM, KNN, dan CNN cukup layak untuk digunakan dalam melakukan klasifikasi citra Chest X-ray dengan hanya menggunakan fitur intensitas pixel. Namun memang algoritma CNN membutuhkan waktu eksekusi pada proses training yang cukup lama yaitu hampir satu jam dengan jumlah data 3886 citra Chest $X$-ray yang terbagi menjadi tiga jenis citra, yaitu Normal, Covid-19, dan Viral Pneumonia.

Pemilihan algoritma untuk klasifikasi citra Chest $X$-ray sangat bergantung pada kebutuhan peneliti. CNN memiliki waktu yang cukup lama dalam melakukan proses training, namun memiliki performa yang sangat bagus. Sedangkan KNN dan SVM memiliki waktu yang relatif cepat namun performa yang dihasilkan tidak sebagus CNN. Jika peneliti memiliki spesifikasi perangkat keras atau server cloud yang bagus dan menginginkan performa yang bagus, waktu eksekusi CNN mungkin tidak menjadi masalah. KNN dan SVM dapat dipilih jika peneliti ingin mendapatkan model klasifikasi yang membutuhkan waktu eksekusi training yang relatif lebih cepat.

CNN merupakan algoritma yang cukup popular untuk klasifikasi Citra dan terbukti bahwa CNN memiliki performa yang terbaik dibandingkan KNN dan SVM untuk klasifikasi citra Chest $X$-ray. Waktu training yang lama hanya dilakukan di awal untuk membentuk model, sehingga tidak menjadi masalah bagi CNN jika dipilih sebagai algoritma klasifikasi citra Chest X-ray.

CNN dapat digunakan untuk membentuk model klasifikasi pada dataset citra $X$-ray dengan menggunakan dataset training yang berjumlah banyak. Hal ini menyebabkan waktu eksekusi training untuk membentuk model klasifikasi menjadi cukup lama. Saat menunggu proses pembentukan model CNN, peneliti dapat menggunakan algoritma KNN dan SVM untuk melakukan klasifikasi sementara citra Chest X-ray dikarenakan performa kedua algoritma tersebut masih cukup bagus. Setelah model CNN terbentuk, peneliti dapat 

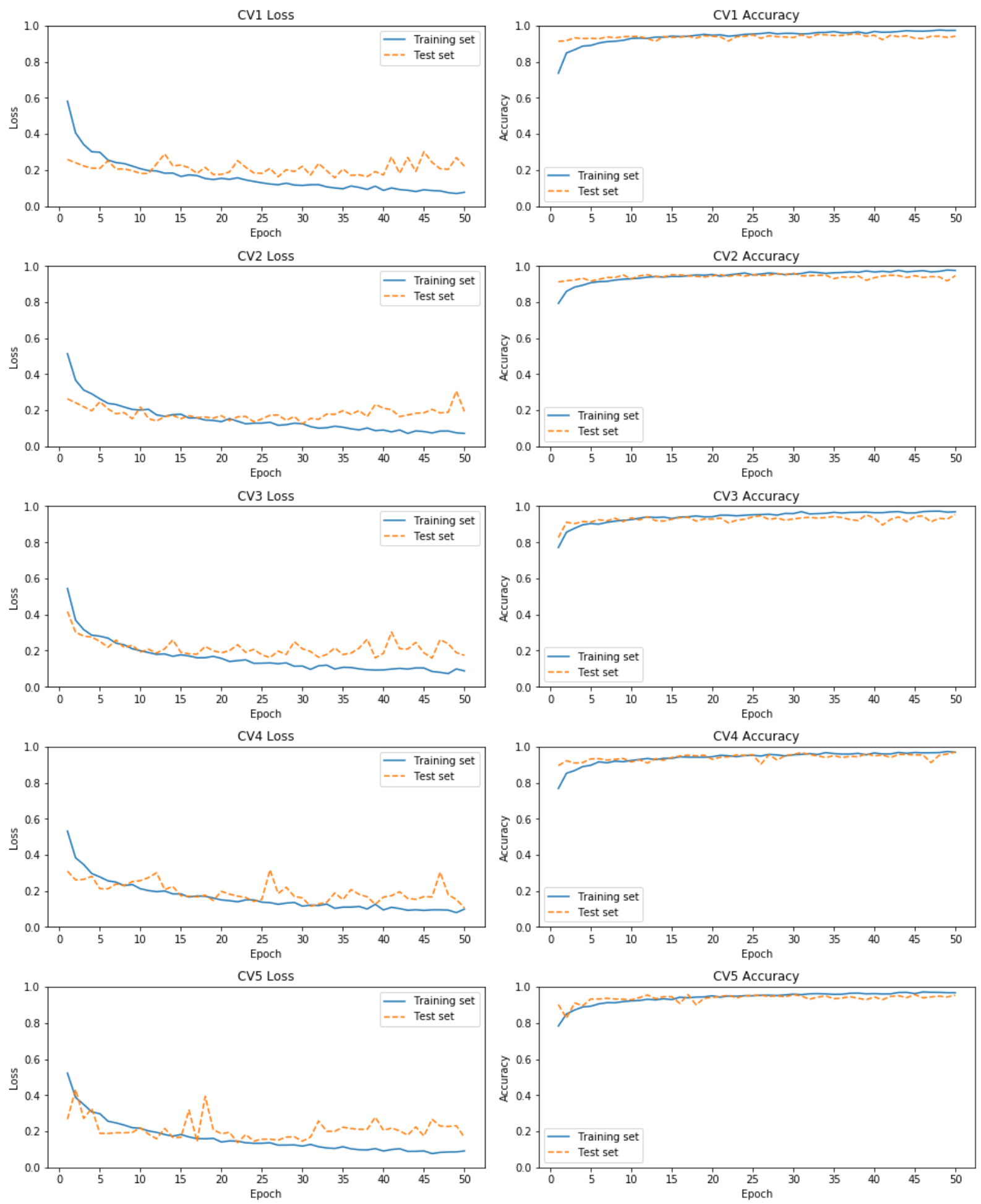

Gambar 4. Grafik Loss dan Accuracy CNN

menggunakan model tersbeut untuk melakukan citra Chest $X$ ray.

\section{KESIMPULAN}

Berdasarkan hasil uji coba yang dilakukan dapat disimpulkan bahwa algoritma KNN, SVM, dan CNN cukup baik dalam melakukan klasifikasi citra Chest X-ray dengan menggunakan 5 cross validation pada data citra sebanyak 3886. Performa KNN dan SVM cukup bagus yaitu masingmasing memiliki akurasi 0,921 dan 0,93. Waktu eksekusi training KNN dan SVM juga cukup cepat yaitu masingmasing 49,49 dan 32,801 detik. CNN memiliki perofrma 
akurasi lebih bagus yaitu 0,9591 namun memiliki waktu eksekusi lebih lama yaitu 3102,562.

Untuk data citra yang banyak, KNN dan SVM dapat digunakan sebagai algoritma sementara dalam melakukan klasifikasi citra Chest $X$-Ray dikarenakan waktu eksekusinya yang lebih cepat. Di saat yang bersamaan CNN dapat dilatih untuk membentuk model klasifikasi. Saat model klasifikasi CNN sudah terbentuk, maka disarankan menggunakan CNN untuk klasifikasi karena memiliki performa yang lebih bagus dibandingkan KNN dan SVM.

Rekomendasi untuk penelitian selanjutnya adalah membandingkan performa berbagai arsitektur CNN yang lain seperti Alex Net [11], VGGNet [12], GoogLeNet [13], ZFNet [14], dan ResNet [15] untuk mendeteksi Covid-19 menggunakan Citra Chest X-Ray. Selain itu penggunaan tahapan preprocessing dapat berguna untuk memperbaiki kualitas citra Chest $X$-ray sehingga meningkat performa metode klasifikasi.

\section{REFERENSI}

[1] Worldometers. (2021). Coronavirus Update (Live): 86,248,818 Cases and 1,863,861 Deaths from COVID19 Virus Pandemic - Worldometer. Diakses dari: https://www.worldometers.info/coronavirus/ pada tanggal 5 Januari 2021.

[2] Shi, H., et.al. (2020). Radiological Findings From 81 Patients With COVID-19 Pneumonia in Wuhan, China: a Descriptive Study. Lancet Infectious Diseases, Vol. 20(4), pp. 425-434. DOI: 10.1016/S14733099(20)30086-4.

[3] Islam, N., et.al. (2020). Thoracic Imaging Tests for the Diagnosis of COVID-19. Cochrane Database of Systematic Reviews. DOI: 10.1002/14651858.CD013639.pub4.

[4] Yasin, R. \& Gouda, W. (2020). Chest X-ray Findings Monitoring COVID-19 Disease Course and Severity. Egyptian Journal of Radiology and Nuclear Medicine, vol. 51. DOI: 10.1186/s43055-020-00296-X.

[5] Gao, T. (2020). Chest X-ray Image Analysis and Classification for COVID-19 Pneumonia Detection Using Deep CNN. medRxiv, DOI:
10.1101/2020.08.20.20178913.

[6] Abbas, A., Abdelsamea, M.M. \& Gaber, M.M. (2020). Classification of COVID-19 in Chest X-ray Images Using DeTraC Deep Convolutional Neural Network. Artificial Intelligence Applications for COVID-19, Detection, Control, Prediction, and Diagnosis. DOI: 10.1007/s10489-020-01829-7.

[7] Deng, X., Shao, H., Shi, L., Wang, X. \& Xie, T. (2020). A Classification-detection Approach of COVID-19 Based on Chest X-ray and CT by Using Keras Pretrained Deep Learning Models. Computer Modeling in Engineering \& Sciences, Vol. 125(2), pp. 579-596. DOI: $10.32604 / \mathrm{cmes} .2020 .011920$.

[8] Rahman, T. (2020). COVID-19 Radiography Database. Dakses dari: https://www.kaggle.com/tawsifurrahman/ covid19-radiography-database pada tanggal 7 Januari 2021.

[9] Chollet, F. (2020). Keras: the Python Deep Learning API. Keras: the Python Deep Learning API. Diakses dari https://keras.io/ pada tanggal 18 Desember 2020.

[10] Goldman, R.N. (1991). More Matrices and Transformations: Shear and Pseudo-perspective. Graphics Gems II, pp. 338-341.

[11] Gonzalez, T.F. (2007). Handbook of Approximation Algorithms and Metaheuristics. DOI: 10.1201/9781420010749.

[12] Simonyan, K. \& Zisserman, A. (2015). Very Deep Convolutional Networks for Large-scale Image Recognition. International Conference on Learning Representations (ICLR 2015).

[13] Szegedy, C., et.al. (2015). Going Deeper with Convolutions. 2015 IEEE Conference on Computer Vision and Pattern Recognition (CVPR), pp. 1-9. DOI: 10.1109/CVPR.2015.7298594.

[14] Zeiler, M.D. \& Fergus, R. (2014). Visualizing and Understanding Convolutional Networks. Lecture Notes in Computer Science, vol. 8689, pp. 818-833. DOI: 10.1007/978-3-319-10590-1_53.

[15] He, K., Zhang, X., Ren, S. \& Sun, J. (2016). Deep Residual Learning for Image Recognition. IEEE Conference on Computer Vision and Pattern Recognition (CVPR), pp. 770-778. DOI: 10.1109/CVPR.2016.90. 